\title{
DAMPAK LAIN CARA BELAJAR TANPA TATAP MUKA TERHADAP PENINGKATAN PENGETAHUAN SISWA SD
}

\author{
Purnami \\ Guru SDN Karangtengah IV Wonosari \\ purnami_hanum@yahoo.co.id
}

\begin{abstract}
Abstrak
Tujuan penelitian adalah mendeskripsikan dampak atau pengaruh lain dari belajar tanpa tatap muka terhadap peningkatan pengetahuan siswa kelas VI pada SD Negeri Karangtengah IV. Pemahaman siswa dapat meningkat apabila siswa paham terhadap materi yang diberikan. Pembelajaran yang dilaksanakan terkait dengan model belajar tanpa tatap muka. Penelitian ini menggunakan pendekatan kualitatif. Data penelitian dijaring menggunakan observasi dan wawancara. Data dianalisis menggunakan teknik reduksi data, displai data, dan penarikan simpulan atau verifikasi. Hasil penelitian menunjukkan bahwa pembelajaran tanpa tatap muka (daring), sebagai akibat berlangsungnya pandemi covid 19 yang dirasakan sebagai penderitaan masyarakat dunia, di satu sisi, justru berdampak positif di sisi lain, yakni dapat meningkatkan pemahaman siswa atas ilmu pengetahuan. Pengetahuan siswa dapat meningkat karena siswa menjadi terlatih atau terampil menggunakan berbagai media pembelajaran, satu hal yang sulit terlaksana ketika pembelajaran selalu dilaksanakan secara tatap muka (luring).
\end{abstract}

Kata Kunci: peningkatan pemahaman, ilmu pengetahuan, belajar tanpa tatap muka

\section{PENDAHULUAN}

Belajar adalah kemampuan anak untuk melakukan upaya perubahan atas dirinya. Wina (Sanjaya, 2008) mengatakan bahwa belajar dianggap sebagai proses perubahan perilaku sebagai akibat dari pengalaman dan latihan. Proses perubahan tingkah laku tersebut memberikan gambaran mengenai bagaimana perkembangan dirinya.

Dimyati dan Mudjiono (2006) mengatakan bahwa belajar adalah suatu proses internal yang kompleks. Yang terlibat dalam proses internal tersebut meliputi unsur afektif, yang matra afektif itu berkaitan dengan sikap, nilai-nilai, interes, apresiasi, dan penyesuaian perasaan sosial.

Belajar merupakan proses berubahnya perilaku seseorang yang dimulai dari diri sendiri. Belajar dapat pula diartikan sebagai suatu proses berubahnya seseorang, perubahan dari belum baik menjadi lebih baik. Seseorang yang belajar akan mengalami proses menuju lebih baik. Belajar juga merupakan kegiatan yang memerlukan waktu dan proses. Belajar yang dimulai dari dirinya pada akhirnya berpengaruh terhadap lingkungannya.
Belajar adalah proses perubahan perilaku berkat pengalaman beserta latihan (Djamarah dan Zain, 2010). Tujuan kegiatan pembelajaran adalah perubahan tingkah laku, baik yang menyangkut pengetahuan, keterampilan, maupun sikap, bahkan meliputi segenap aspek organisme atau pribadi masing-masing.

Proses pembelajaran pada dewasa ini terkait dengan terjadinya musibah pandemi covid 19 tidak atau belum bisa dilaksanakan secara langsung, melainkan melalui kegiatan dalam jaringan (daring). Kegiatan daring dilaksanakan melalui kegiatan pembelajaran jarak jauh (PJJ) atau tanpa tatap muka. Proses Pembelajaran dilakukan dari tempat masingmasing yang berbeda. Daring memerlukan sarana, salah satunya adalah jaringan internet.

Dalam kegiatan pembelajaran komunikasi sangat diperlukan. Komunikasi dalam hal ini memiliki pengertian proses penyampaian pikiran atau perasaan oleh seseorang kepada orang lain dengan menggunakan lambang-lambang yang bermakna bagi kedua belah pihak. Dalam situasi tertentu komunikasi menggunakan media tertentu 
untuk mengubah sikap atau tingkah laku seseorang atau sejumlah orang. Dari komunikasi tersebut diharapkan menghasilkan efek tertentu (Effendi, 2003: 13).

Komunikasi daring sebenarnya sudah dimulai sejak zaman dulu. Hanya saja pada waktu itu belum ada gawai atau masih menggunakan komputer. Berkat semakin berkembangnya perkomunikasian itu, daring mengalami kemajuan. Daring dapat digunakan melalui perangkat milik pribadi berupa gawai atau handphone.

Sebelum adanya penyebaran covid 19, sudah banyak masyarakat yang menggunakan komunikasi daring ini. Daring dapat dimaknai sebagai kegiatan yang mengacu pada kegiatan membaca, menulis, dan berkomunikasi melalui jaringan komunikasi (Warschauer, 2001: 207-212). Terkait dengan merebaknya wabah pandemi covid 19, pelaksanaan pembelajaran tanpa tatap muka atau daring cukup dibutuhkan mengingat sistem daring mampu memberikan resiko terkecil dalam penularan virus corona. Yang utama ingin dicapai adalah kestabilan dalam meningkatkan ilmu pengetahuan peserta didik, baik di lingkungan sekolah maupun lingkungan peserta didik.

Berdasarkan proses yang terjadi pada pembelajaran tanpa tatap muka ini, proses transfer ilmu pengetahuan diprediksi akan lebih sulit. Hal itu dikarenakan masing-masing peserta didik memiliki kemampuan yang berbeda-beda dalam penyerapan ilmu pengetahuan. Diperlukan metode yang tepat agar pembelajaran lebih bermakna, meskipun tanpa melalui proses tatap muka. Hal ini memerlukan perhatian khusus, salah satunya dengan analisis kebutuhan peserta didik.

Berangkat dari latar belakang di atas, permasalahan yang akan dijawab dalam penelitian ini adalah melalui pembelajaran tanpa tatap muka apakah pemahaman siswa SD atas pengetahuan dapat meningkat. Beberapa pertanyaan fokus yang dapat dirumuskan adalah (a) bagaimana kegiatan pemilihan cara pembelajaran tanpa tatap muka dilakukan; (b) bagaimana pembelajaran tanpa tatap muka untuk meningkatkan pemahaman atas pengetahuan dilaksanakan; (c) apa saja kendala yang dihadapi dalam pelaksanaan pembelajaran tanpa tatap muka; (d) bagaimana evaluasi pelaksanaan pembelajaran tanpa tatap muka dilakukan; dan (e) efektifkah pembelajaran tanpa tatap muka untuk meningkatkan pemahaman atas pengetahuan.

\section{METODE}

Subjek penelitian ini adalah siswa kelas VI SD Negeri Karangtengah IV tahun pelajaran 2019/2020 yang berjumlah 28 orang. Penentuan subjek penelitian dilakukan mengacu pada keadaan anak dan lingkungan. Subjek diambil berdasarkan peserta didik pada kelas enam dan berdasarkan peraturan pemerintah harus melaksanakan pembelajaran tanpa tatap muka.

Penelitian ini dilaksanakan di SD Negeri Karangtengah IV, yang berlokasi di Kedung I, Karangtengah, Wonosari, Kabupaten Gunungkidul, Daerah Istimewa Yogyakarta. Sekolah ini termasuk dalam lokasi yang terdampak pandemi covid 19 . Karena mereka belajar dari rumah, maka interaksi dilaksanakan melalui pembelajaran tanpa tatap muka.

Penelitian dilaksanakan pada Maret 2019 sampai dengan Mei 2019. Penelitian ini menggunakan pendekatan kualitatif. Subjek penelitian ini direkrut menggunakan teknik purposif, dengan pertimbangan agar data yang diperoleh lebih representatif (Sugiyono, 2014: 32).

Dalam penelitian ini peneliti merupakan instrumen utama. Dalam penjaringan asil dan pembahasan.data peneliti dipandu dengan panduan observasi, panduan wawancara mendalam, dan panduan studi dokumentasi. Untuk uji keabsahan data digunakan teknik triangulasi. Data yang dihasilkan dengan teknik observasi dan wawancara mendalam dianalisis dengan tahapan: reduksi data, displai data, dan penarikan simpulan atau verifikasi (Sugiyono, 2014: 60).

\section{HASIL DAN PEMBAHASAN}

Penugasan tanpa tatap muka, daring, atau online yang dilakukan di rumah siswa tidak dapat lepas dari peran serta orang tua. Dari awal kegiatan sampai dengan kegiatan pembelajaran 
berakhir, siswa mesti mendapatkan bimbingan atau pendampingan dari orang tua. Demikian halnya, ketika terjadi masalah atau kesulitan, orang tua perlu berkomunikasi dengan guru. Untuk itu, dibutuhkan adanya jalinan komunikasi yang baik antara keduanya.

Kegiatan pembelajaran tanpa tatap muka ini berawal dari adanya penyebaran virus corona yang konon berasal dari Wuhan, Cina pada 2019 (http://www.kompas.com). Seperti lajunya angin, penyebaran tersebut tidak dapat dibendung lagi, hingga akhirnya sampai di Indonesia pada akhir Desember 2019. Mewabahnya virus ini sangat berpengaruh terhadap segala hal. Semua fasilitias umum ditutup. Penerapan lockdown, physical distancing, social distancing diberlakukan hampir di semua aspek kehidupan. Tidak terkecuali bidang pendidikan pun terdampak cukup serius.

Kegiatan pembelajaran mengacu pada aturan Pemerintah, yakni tidak boleh melakukan kontak fisik dari Maret 2020. Pada akhir bulan itu, mau tidak mau pembelajaran dialihkan pada pemanfaatan teknologi informatika dengan menggunakan sarana internet (https://guruberbagi.kemdikbud.go.id).Hal ini tentu menjadi hal yang baru bagi peserta didik yang tinggal di daerah pedesaan yang jauh dari jaringan. Peserta didik dipaksa untuk mengikuti pembelajaran menggunakan segala fasilitas dan bentuk pembelajaraan yang baru. Mereka harus bisa menyesuaikan pembelajaran yang baru tersebut agar semua informasi dan transfer informasi dapat mereka terima dengan baik, tanpa ada kendala atau kesulitan yang berarti.

Awal pembelajaran tanpa tatap muka ini berawal dari adanya pandemi. Pandemi adalah wabah yang muncul serentak di mana-mana, meliputi wilayah dengan geografis yang luas. Suatu penyakit dikatakan pandemi apabila penyakit itu masuk dalam kategori menular dan memiliki garis infeksi yang berkelanjutan. Terjadinya kasus di beberapa negara yang bukan negara asal penyakit tersebut dapat dikategorikan sebagai pandemi.

Pada awalnya pembatasan "belajar dari rumah" (BDR) atau tanpa tatap muka (dengan fasilitas daring) itu ditanggapi secara beragam.
Pada minggu pertama, anak didik merasa senang karena mendapatkan "jatah libur" lebih dari biasanya. Namun, ketika mereka dihadapkan kepada kenyataan selanjutnya, yaitu pembelajaran harus tetap berlangsung dan itu harus melibatkan banyak pihak, termasuk orang tua beserta keluarga, ternyata terjadi banyak kendala. Kendala-kendala tersebut di antaranya banyak orang tua yang kurang mampu memberikan pendampingan kepada anak, dilatarbelakangi pendidikan orang tua yang beragam. Selain itu, adanya tambahan dana untuk pembelian quota internet juga menjadi permasalahan tersendiri.

Kegiatan pembelajaran tanpa tatap muka ini, secara kebetulan, dilaksanakan ketika anak didik dalam situasi menghadapi ujian sekolah berstandar nasional (USBN) yang menurut rencana akan dilaksanakan pada April 2020. Namun, sebelum USBN dilaksanakan, pandemi pun melanda. Terjadilah dilema antara berharap USBN akan tetap dilaksanakan dan kenyataan bahwa pembelajaran secara tatap muka belum bisa dilaksanakan. Maka, guru sebagai fasilitator perlu merancang cara atau metode pembelajaran yang paling tepat agar permasalahan yang terjadi di lapangan dapat diatasi, sekaligus tidak menimbulkan masalah baru. Dengan menggunakan gawai atau hand phone atau smart phone, pembelajaran tanpa tatap muka dilaksanakan. Namun, keberhasilan tersebut tidak lepas dari adanya kolaborasi antara guru, orang tua siswa, dan peserta didik itu sendiri.

Untuk pelaksanaan pembelajaran pada umumnya, misalnya, diperlukan keterampilan mengajar oleh guru. Sebelum melaksanakan pembelajaran secara daring atau tanpa tatap muka, guru harus mampu membuat rencana pembelajaran (RPP?) terlebih dahulu. Rencana pembelajaran ini yang akan dipergunakan sebagai barometer pelaksanaan pembelajaran selanjutnya. Penyusunan rencana pembelajaran ini dilakukan dengan memangkas bagian-bagian yang dianggap terlalu panjang, untuk diubah menjadi rencana pembelajaran yang menarik, dan akhirnya dapat dilaksanakan secara online melalui pembelajaran daring. Model itulah yang akhirnya dilaksanakan 
yakni melalui pembelajaran tanpa tatap muka selama masa pandemi berlangsung.

Terkait dengan hal-hal yang tersebut di atas, kesiapan peserta didik pun ternyata perlu mendapatkan perhatian. Banyak faktor perlu diperhatikan agar pembelajaran online bisa berjalan dengan lancer, banyak hal perlu dipertimbangkan dalam melakukan pembelajaran tanpa tatap muka. Anak didik lebih familier dengan menggunakan WhatsApp atau WA. Langkah pertama yang dilakukan adalah berusaha melakukan pembelajaran dari hal yang paling ringan. Jika itu sudah bisa berjalan, pembelajaran yang lain menyusul. Tidak memberikan sesuatu yang memang belum bisa dijalankan. Semua itu diikuti dengan tertib, dilakukan analisis dampak dan seterusnya agar pembelajaran dapat berjalan dengan tepat dan lancar.

Pembelajaran tanpa tatap muka pun memerlukan guru yang kreatif, baik dalam menyiapkan kegiatan/pengalaman belajar siswa, dalam memilih kompetensi dari berbagai mata pelajaran dan mengaturnya agar pembelajaran menjadi lebih bermakna, memberikan kesan yang menarik, tanpa menghilangkan unsur yang ada dalam pembelajaran itu.

Pembelajaran secara tanpa tatap muka dilakukan dengan cara mempersiapkan terlebih dahulu materi yang akan disampaikan, kemudian memberikan pengertian mengenai pembelajaran yang akan dilaksanakan melalui pembelajaran daring, melalui forum orang tua siswa. Dalam forum itu disampaikan bahwa pembelajaran akan dilaksanakan melalui pembelajaran tanpa tatap muka, selama masa pandemi covid 19, dengan dengan batas waktu yang belum ditentukan. Untuk itu, guru meminta izin kepada orang tua untuk memperbolehkan putra-putrinya belajar dari rumah menggunakan media pembelajaran secara online.

Pelaksanaan selanjutnya yang harus dilakukan guru adalah membentuk kelompok (grup WA) yang anggotanya peserta didik kelas 6 . Persiapan yang dilakukan adalah pengorganisasian pembelajaran, di antaranya menyediakan fasilitas yang diperlukan dalam proses pembelajaran. Pembelajaran yang dilakukan tersebut, meskipun masih dalam ranah tematik terpadu, namun dalam pelaksanaannya tidak bisa penuh seperti pembelajaran dengan tatap muka.

Tahap yang dilakukan selanjutnya adalah pelaksanaan serta pengawasan pembelajaran. Pembelajaran merupakan gabungan yang tertata yang meliputi segala unsur manusiawi, perlengkapan pembelajarannya, fasilitas, prosedur yang saling mempengaruhi dalam mencapai tujuan pembelajaran (Hamalik, 2003: 54). Mempersiapkan peserta didik untuk mengikuti kegiatan pembelajaran tanpa tatap muka menjadi hal yang penting. Meskipun kegiatan ini hanya berlaku pada masa pandemi covid 19, tujuannya tetap membantu peserta didik untuk menghadapi kehidupannya kelak ketika mereka terjun di masyarakat.

Pelaksanaan pembelajaran tanpa tatap muka diawali dengan pembentukan grup, mengecek anak lewat grup, kemudian memberikan tugas pertama. Tugas itu berupa perkenalan yang bisa dilaksanakan dengan video perkenalan mereka. Perkenalan dibuat dengan membuat video yang kemudian dikirim ke grup WA. Setelah itu, pembelajaran dimulai sesuai dengan materi yang sudah direncanakan, malaupun materi tersebut jangan sampai memberatkan anak didik.

Tahap akhir dari manajemen pembelajaran adalah evaluasi. Gultom (2014: 30) menyatakan bahwa penilaian autentik adalah proses evaluasi untuk mengukur kinerja-kinerja, prestasi, motivasi, dan sikap-sikap siswa pada aktivitas pembelajaran. Penilaian dilakukan melalui tugas-tugas yang dikirim melalui WA maupun dikumpulkan dalam tugas tertulis/luring.

Dalam mempersiapkan kegiatan pembelajaran yang bermakna tersebut diperlukan kesiapan siswa untuk melaksanakannya. Minat anak didik bisa ditingkatkan melalui hasil yang dikirimkannya. Kombinasi pembelajaran dapat menarik minat peserta didik. Misalnya, penugasan diberikan melalui WA, Google classroom, ataupun media yang lain. Pada prinsipnya, semakin banyak kombinasi pembelajaran akan semakin baik pula hasilnya. 
Berdasarkan analisis data yang dilakukan dapat diperoleh temuan-temuan sebagai berikut.

a. Kegiatan Pemilihan Cara Pembelajaran Tanpa Tatap Muka

Kegiatan pembelajaran tanpa tatap muka di SD Negeri Karangtengah IV meliputi kegiatan perencanaan, pelaksanaan, pengawasan, dan evaluasi. Selain itu, perlu dicari kendala yang ada di lapangan, sehingga untuk pelaksanaan selanjutnya dapat lebih baik lagi. Peningkatan pemahaman siswa atas ilmu pengetahuan juga perlu dipertimbangkan agar nantinya tidak menimbulkan kemunduran prestasi peserta didik.

Kegiatan perencanaan pembelajaran yang dilakukan adalah pemilihan materi yang tepat dan sesuai dengan karakteristik peserta didik, dimulai dari hal yang paling sederhana yang terdekat dengan anak, meskipun pada akhirnya mengejar materi sesuai dengan yang didapat. Materi juga disesuaikan dengan kebutuhan pada saat terjadi pandemi covid 19.

Setelah kegiatan perencanaan dilaksanakan, langkah berikutnya adalah pemilihan langkah awal pembelajaran. Langkah itu adalah memberikan materi kepada peserta didik, yang pada awalnya memberikan materi yang ada kaitannya dengan peserta didik. Tugas ringan yang diberikan berfungsi untuk memberikan rangsangan agar peserta didik mampu mengerjakan pembelajaran selanjutnya.

Penugasan dimulai dengan pemberian tugas awal melalui perkenalan, pembuatan poster, dan sebagainya. Pembuatan poster mesti ada kaitannya dengan covid 19. Selain materi yang ada kaitannya dengan bahan pelajaran, pembiasaan juga ditekankan, meliputi bangun pagi, beribadah sesuai agama masing-masing, membantu orang tua menyiapkan sarapan, membersihkan rumah dan lingkungan, dan menyelesaikan tugas-tugas yang di-online-kan. Kegiatan baru seperti berjemur, cuci tangan sebelum dan sesudah melaksanakan kegiatan juga dibiasakan agar mereka terhindar dari virus yang mungkin ada.

Persiapan berikutnya adalah membuat rencana pembelajaran yang disesuaikan dengan kondisi. Rencana pembelajaran itu berjangka waktu lebih pendek daripada biasanya. Kalau biasanya rencana pembelajaran dilakukan selama satu semester, namun untuk rencana pembelajaran yang dibuat selama pendemi ini berjangka waktu lebih pendek, misalnya rencana pembelajaran mingguan. Materi pembelajaran disesuaikan dengan kemampuan anak, dimulai dari yang ringan hingga yang berat.

Setelah mempersiapkan materi pembelajaran, guru memberikan jadwal pembimbingan kepada peserta didik. Peserta didik diarahkan untuk melaksanakan proses pembelajaran sesuai dengan arahan melalui pembelajaran tanpa tatap muka.

b. Pelaksanaan Pembelajaran Tanpa Tatap Muka untuk Meningkatkan Pemahaman atas Pengetahuan

Pembelajaran tanpa tatap muka yang dilaksanakan adalah pembelajaran kepada siswa yang telah melaksanakan pembelajaran paling lama, siswa yang hampir lulus dari sekolah. Materi pembelajaran disesuaikan dengan materi akhir. Sebelum itu, pembelajaran diarahkan untuk mempersiapkan pelaksanaan Ujian Akhir Sekolah Berstandar Nasional.

Pada awalnya diberikan tugas yang ringan, di antaranya memberikan tugas langsung kepada peserta didik, berupa tugas pembiasaan yang mesti dilakukan setiap hari oleh peserta didik. Tugas itu berupa pembiasaan mencuci tangan setiap pagi dan sore hari. Kebiasaan baik yang dilakukan yakni memfoto kegiatan membersihkan lingkungan, membantu memasak, dan kegiatan positif yang lain. Untuk hari pertama kegiatan tanpa tatap muka dilaksanakan dengan menjadwal kegiatan, untuk hari yang kedua sampai dengan seminggu pertama kegiatan difokuskan pada kegiatan yang berkaitan langsung dengan peserta didik.

Untuk kegiatan minggu kedua, mulai disisipkan materi sedikit demi sedikit, namun tetap dipilihkankegiatanyang merangsang kreativitasanak didik yang langsung berhubungan dengan mereka. Selain materi pembelajaran, mereka diminta untuk membuat sesuatu yang mereka senangi, misalnya 
membuat masakan. Mereka dimintai memfoto atau memvideo kegiatan tersebut.

Pembelajaran dilaksanakan tidak untuk memberatkan peserta didik, namun untuk menambah ilmu pengetahuan. Oleh karena itu, pemberian tugas juga harus seimbang, artinya tugas itu menyasar pada tujuan peningkatan ilmu pengetahuan dan untuk meningkatkan imun peserta didik. Penugasan materi yang dirasakan terlalu berat bagi peserta didik diubah menjadi pemberian tugas yang menggugah semangat untuk terus mengembangkan kreativitas dan kepekaan terhadap hal-hal yang berkaitan dengan mereka. Peserta didik diajak untuk tidak terlalu terkekang selama pandemi agar imunitas mereka terjaga.

Pada bulan kedua pelaksanaan BDR, sudah tampak adanya penyesuaian antara tugas dan peserta didik. Peserta didik secara berkala mengirimkan tugas yang sudah dikerjakan dengan baik.

Pada akhirnya, guru melakukan pengamatan terhadap perubahan pembelajaran tanpa tatap muka yang dilaksanakan. Tampak bahwa pembelajaran tanpa tatap muka memberikan kontribusi terhadap perkembangan pemahaman ilmu pengetahuan peserta didik. Sampai dengan selesai pembelajaran, peserta didik mampu mengikuti perkembangan ilmu pengetahuan meskipun tanpa tatap muka.

c. Kendala Pelaksanaan Pembelajaran Tanpa Tatap Muka dalam Peningkatan Pemahaman atas Pengetahuan

Dalam pelaksanaan pembelajaran tanpa tatap muka ada beberapa kendala yang muncul, di antaranya fasilitas yang tidak merata. Bagaimanapun, pembelajaran tanpa tatap muka memerlukan waktu yang lebih lama karena anak-anak tidak atau belum memiliki android atau gawai sendiri, sehingga pesan pembelajaran tidak bisa langsung sampai kepada anak. Demikian pula, lokasi tempat tinggal juga cukup berpengaruh. Tidak semua lokasi lancar dengan internet.

Kesulitan anak didik untuk bia selalu membeli paket internet yang dibutuhkan tampaknya juga menjadi kendala tersendiri. Di samping, ada peserta didik yang melaksanakan tugas-tugas mereka secara pasif, hanya melaksanakan tugas sesuai dengan yang diinstruksikannya.

\section{d. Evaluasi terhadap Pelaksanaan Pembelajaran Tanpa Tatap Muka \\ Pelaksanaan kegiatan pembelajaran tanpa} tatap muka dapat dilakukan dengan beberapa penilaian. Penilaian itu diambil dari pengamatan atas hasil dari setiap kali siswa menyampaikan tugas-tugas online yang diberikan guru. Peran guru dan peralatan dalam kegiatan pembelajaran tanpa tatap muka perlu dievaluasi. Gultom (2014: 30) menyatakan bahwa penilaian merupakan proses evaluasi untuk mengukur kinerja, prestasi, motivasi, dan sikap-sikap siswa dalam kaitannya dengan aktivitas pembelajaran. Perbedaan pendapat yang terjadi antartutor sebaya dalam kelompok menjadi tugas guru sebagai fasilitator untuk segera memberikan masukan secara netral.

\section{e. Efektivitas Pembelajaran Tanpa Tatap Muka dalam Meningkatkan Pemahaman Siswa atas Pengetahuan \\ Pelaksanaan pembelajaran tanpa tatap} muka untuk meningkatkan kompetensi siswa atas pengetahuan di era pandemi cukup efektif. Hal itu dapat dilihat dari peningkatan keberhasilan siswa dalam mengerjakan tugas-tugas yang diberikan kepada mereka. Ukuran keberhasilanyang digunakan adalah tugas-tugas yang diberikan kepada anak didik dapat diselesaikan sebagaimana mestinya, yakni banyak siswa yang mampu mengerjakan tugas dengan hasil yang relatif tepat waktu, benar, dan meningkatnya kesadaran siswa untuk hidup secara lebih aman dan nyaman, sehingga, semakin kecil pula peluang mereka untuk terpapar virus.

\section{SIMPULAN}

Berdasarkan pembahasan di atas, hasil penelitian ini menunjukkan bahwa cara pembelajaran tanpa tatap muka di era pandemi pada siswa kelas VI SD Negeri Karangtengah IV sudah dipilih secara tepat. Pembelajaran tanpa tatap muka di samping menimbulkan berbagai kendala dalam pembelajaran, model ini dapat dilaksanakan 
untuk meningkatkan pemahaman siswa atas pengetahuan, kendala-kendala yang muncul dapat diselesaikan secara bijak, evaluasi terus dilakukan, dan pembelajaran tanpa tatap muka di era pandemi cukup efektif dalam meningkatkan pemahaman siswa atas pengetahuan.

Pembelajaran tanpa dengan tatap muka (daring, online, PJJ) di era pandemi covid 19, di samping memiliki banyak kendala teknis maupun nonteknis, namun ternyata mampu meningkatkan pemahaman siswa atas pengetahuan yang cukup diperlukan di era pandemi, sehingga anak didik bisa mengimplementasikan pola hidup sehat. Kebutuhan pengetahuan peserta didik yang tidak akan diperoleh melalui pembelajaran dengan tatap muka dapat dipenuhi oleh pembelajaran dengan tanpa tatap muka.

Kekhawatiran mengenai ketidaksanggupan peserta didik untuk mengadaptasi pengetahuan yang dibutuhkan untuk mengantisipasi kehidupan mereka di era pandemi ternyata tidak terjadi. Bantuan guru sebagai fasilitator dan peran orang tua sebagai pendamping anak didik secara kolaboratif membuat peserta didik mampu meningkatkan pengetahuan mereka, mampu bertahan, bahkan mampu meningkatkan daya imunitas mereka.

\section{DAFTAR PUSTAKA}

Djamarah. S. B. Zain. A. 2010. Strategi Belajar Mengajar. Jakarta: Rineke Cipta.

Dimyati, Mudjiono. 2006. Belajar dan Pembelajaran. Jakarta: Rineke Cipta.

Effendi, Onong. 2000. Ilmu Teori dan Filsafat Komunikasi. Bandung: PT Rosdakarya.

Gultom. 2013. Materi Pelatihan Guru: Implementasi

Kurikulum 2013. Jakarta: Departemen Pendidikan dan Kebudayaan.

Hamalik, Oemar. 2003. Proses Belajar Mengajar. Jakarta: PT Bumi Aksara.

https://guruberbagi.kemdikbud.go.id

http://www.kompas.com

Sanjaya, Wina. 2008. Strategi Pembelajaran Berorientasi Standar Proses Pendidikan. Jakarta: Prenada Media.
Sugiyono. 2007. Metode Penelitian Pendidikan Pendekatan Kuantitatif, Kualitatif, dan $R \& D$. Bandung: Alfabeta.

Sungkono. 2010. Pembelajaran Tematik dan Implementasinya. Bandung: Rosdakarya.

Tarigan, Henry Guntur. 2008. Membaca suatu Keterampilan Bahasa. Bandung: Percetakan Angkasa.

Warschauer, M. 2001. Online Communic

Hisyam, Zaini, dkk. 2008. Strategi Pembelajaran Aktif. Yogyakarta: Pustaka Insani Madani. 